\title{
Bioactive peptides released from in vitro digestion of human milk with or without pasteurization
}

\author{
Yasuaki Wada ${ }^{1,2}$ and Bo Lönnerdal ${ }^{1}$
}

BACKGROUND: Pasteurized donor human milk (HM) serves as the best alternative for breast-feeding when availability of mother's milk is limited. Pasteurization is also applied to mother's own milk for very low birth weight infants, who are vulnerable to microbial infection. Whether pasteurization affects protein digestibility and therefore modulates the profile of bioactive peptides released from HM proteins by gastrointestinal digestion, has not been examined to date.

METHODS: $\mathrm{HM}$ with and without pasteurization $\left(62.5^{\circ} \mathrm{C}\right.$ for $30 \mathrm{~min}$ ) were subjected to in vitro gastrointestinal digestion, followed by peptidomic analysis to compare the formation of bioactive peptides.

RESULTS: Some of the bioactive peptides, such as caseinophosphopeptide homologues, a possible opioid peptide (or propeptide), and an antibacterial peptide, were present in undigested HM and showed resistance to in vitro digestion, suggesting that these peptides are likely to exert their bioactivities in the gastrointestinal lumen, or be stably transported to target organs. In vitro digestion of HM released a large variety of bioactive peptides such as angiotensin l-converting enzyme-inhibitory, antioxidative, and immunomodulatory peptides. Bioactive peptides were released largely in the same manner with and without pasteurization.

CONCLUSION: Provision of pasteurized HM may be as beneficial as breast-feeding in terms of milk protein-derived bioactive peptides.

$\mathbf{H}$ uman milk (HM) is highly recommended as the optimal mode of infant feeding for the first several months of life. It serves as a source of nutrients with excellent bioavailability as well as multiple bioactive substances, contributing to growth, development, and health. Recent studies have made it more evident that breast-feeding may reduce the risk of metabolic disease later in life (1-3). When the mother's own milk is limited for several reasons, donor HM is advocated over infant formulas as HM is superior to infant formula in terms of immunoprotection and gastrointestinal development (4). Donor HM is commonly pasteurized at $62.5^{\circ} \mathrm{C}$ for $30 \mathrm{~min}$ with a holder (i.e., low-temperature long-time treatment) in order to avoid HM-transmitted bacterial and viral infections (4). Pasteurization is also applied to mother's own milk at some neonatal intensive care units for very low birth weight infants, who are highly vulnerable to cytomegalovirus in HM $(5,6)$. However, this pasteurization may have negative effects on many of the nutrients and bioactive compounds. Pasteurization is accompanied by inactivation of bile salt-stimulated lipase, which may impair absorption of human milk fat and limit infant growth (6). Pasteurization may reduce antioxidants such as ascorbic acid and vitamin $\mathrm{E}$, thereby possibly increasing the susceptibility of the recipient infant to oxidative stress (7). Pasteurization may also reduce immunomodulatory proteins, such as secretory immunoglobulin A and lactoferrin (LF), thereby attenuating the host defense potential (8). Further, metabolic hormones such as adiponectin and insulin also decrease after pasteurization, which may impact metabolic trajectories of infants later in life (9).

Proteins in HM primarily serve as a source of essential amino acids to infants, but they also exert various kinds of bioactivities beneficial to infant health (10). Some of these bioactivities are provided by peptides which are "encrypted" in their parental proteins, and they are exerted only after these peptides are released by the action of gastrointestinal digestive enzymes, membrane peptidases, and/or peptidases in the circulation (11). Although heat treatment is generally considered to affect protein digestibility (12), it is still equivocal whether formation of milk-protein derived bioactive peptides is affected by pasteurization of HM. The aim of this study was to use a peptidomic technique to compare in vitro formation of bioactive peptides released from proteins in HM and pasteurized HM. We have previously developed an in vitro digestion model, taking into account the somewhat higher stomach $\mathrm{pH}$ (4.0) of infants (13). Both HM and pasteurized HM were applied to in vitro digestion with porcine pepsin and pancreatin followed by liquid chromatography coupled with tandem mass spectrometry (LC-MS/MS) analysis, and the released peptides from major proteins, such as caseins (CNs), $\alpha$-lactalbumin $(\alpha-$ LA), LF, and osteopontin (OPN), were searched for bioactivities using established databases. 


\section{RESULTS}

Peptides in undigested HM were analyzed prior to the analysis of digesta as background data (Figure 1), because some of the protein-derived peptides are potentially present in undigested HM $(14,15)$. As can be seen, a large number of peptides were observed. In agreement with previous observations, most of the peptides present in undigested HM were derived from CNs, and no peptide was identified from major whey proteins such as $\alpha$-LA and LF. The most abundant peptides are derived from $\beta-\mathrm{CN}$, reflecting its high susceptibility to plasmin-mediated proteolysis as well as the high content of this casein subunit in HM $(14,16)$. Focusing on bioactive peptides in undigested HM, as shown in Table $1(14,15,17-30)$, two caseinophosphopeptide homologues, a possible opioid peptide or propeptide, and an antibacterial peptide were identified.

In vitro digestion of $\mathrm{HM}$ and pasteurized $\mathrm{HM}$ released a multitude of peptides from CNs and whey proteins (Figure 1); both milk samples released peptides largely in the same way as exemplified by $\beta$-casein (Figure 2). This similarity also holds true for the patterns of bioactive peptides (Table 1). Notable bioactive peptides, released only after in vitro digestion, include angiotensin I-converting inhibitory (ACEi) peptides, antioxidative peptides, and immunomodulatory peptides.

It should be noted that we also extensively searched for bioactive peptides derived from OPN, a multifunctional protein involved in many physiologic processes such as regulation of immune function (31), but no peptide was found that corresponds to any known bioactive peptides (Table 2).

\section{DISCUSSION}

Pasteurization is a common procedure for treating donor HM and mother's own milk of very low birth weight infants in order to prevent HM-transmitted microbial infection. However, pasteurization may be accompanied by adverse effects such as reduction in fat absorption, loss of vitamins, and attenuation of bioactive compounds $(6,7,9)$, although it seems equivocal whether these changes are of significance for neonatal health $(6,32)$. Aiming to further characterize "risks and benefits" of

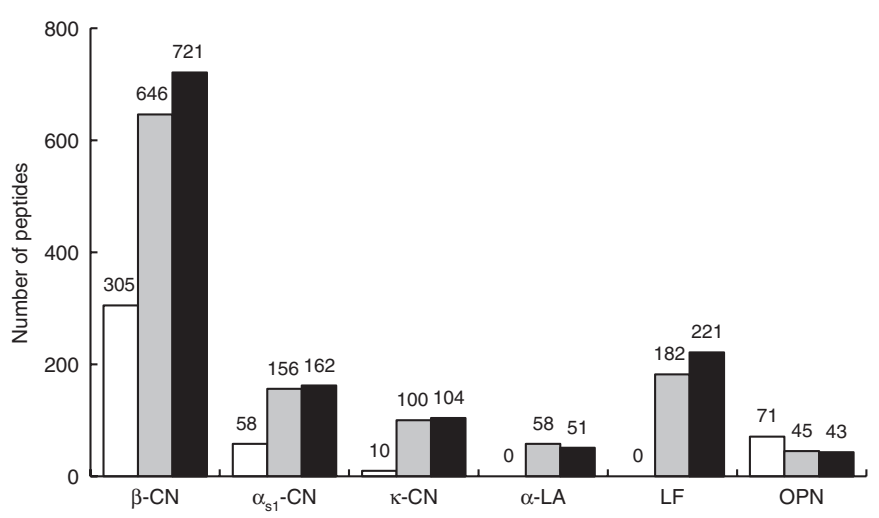

Figure 1. Number of peptides derived from major human milk (HM) proteins. Exclusive peptide counts from $\beta$-casein ( $\beta-\mathrm{CN}), \alpha_{\mathrm{s} 1}-\mathrm{CN}, \kappa-\mathrm{CN}$, $\alpha$-lactalbumin ( $\alpha$-LA), lactoferrin (LF), and osteopontin (OPN) are shown. Open bars, bars in gray, and closed bars indicate counts in undigested HM, digested $\mathrm{HM}$, and digested pasteurized $\mathrm{HM}$, respectively. pasteurization, we compared the patterns of bioactive peptides released from HM and pasteurized HM after in vitro digestion.

The release of bioactive peptides from major milk proteins after in vitro digestion was generally the same for HM and pasteurized HM. We therefore suggest that holder-pasteurization of HM does not affect formation of bioactive peptides to a significant extent, and that the minor differences observed may be attributed to small variations in conditions for in vitro digestion. This result may be corroborated by previous studies, including our own, that high-temperature-short-time-pasteurization of cow's milk results in a digestibility similar to that of raw milk (13). It should be noted, though, that the peptidomic technique used in this study has optimum sensitivity to determine peptides with medium length $(\sim 5-20$ amino acid residues), which encompasses most bioactive peptides reported to date. Detection of shorter peptides is not compatible with this method because these peptides are hardly trapped on the reverse phase column in LC and they give poorer fragmentation in MS/MS (33). Thus, this study inevitably misses the information whether pasteurization of $\mathrm{HM}$ affects formation of bioactive peptides with 2-4 amino acid residues. However, there are only a limited number of peptides of this size and few kinds of bioactivities (e.g., ACEi peptides) have been described for them.

Bioactive peptides derived from major human milk proteins are discussed below.

\section{$\beta$-CN-Derived Bioactive Peptides}

Although the proportion of whey proteins exceeds that of CNs in HM, CNs still constitute a considerable part of proteins and $\beta-\mathrm{CN}$ is dominant among them (16), also serving as the greatest source of bioactive peptides (11).

Four known bioactive peptides (residues 1-18, 1-23, 51-59, and 185-211) were identified in undigested HM, and they were preserved even after in vitro digestion of HM and pasteurized HM. Except residues 51-59, the presence of these peptides in undigested HM has been observed previously $(14,15)$. Two peptides of residues $1-18$ and $1-23$ are considered human counterparts of caseinophosphopeptides because they have the "acid motif" SerP-SerP-SerP-Glu-Glu, essential for the mineral-carrier potential (11). Both of the peptides were confirmed in digested HM and pasteurized HM, suggesting that these peptides would be stable following gastrointestinal digestion and be functional for facilitating mineral uptake. To the best of our knowledge, a peptide of residues 51-59 has not been reported present in undigested HM. This peptide includes the entire sequences of human $\beta$-casomorphins (residues 51-54, 51-55, 51-57, and 51-58) (20), as well as it meets the structural requirements to exert such activity, i.e., a tyrosine residue at the $\mathrm{N}$-terminus followed by another aromatic residue at the third or fourth position, possibly exerting multiple functions in neonates such as gastrointestinal function, mucosal development, and sleep induction (11). This longer peptide would be opioidergic, and/or a pro-opioid peptide like bovine $\beta$-casomorphins; their longer precursor peptides are considered to be absorbed and then they are excised in the blood 


\section{Articles | Wada and Lönnerdal}

Table 1 Bioactive peptides released from proteins in human milk and pasteurized human milk

\begin{tabular}{|c|c|c|c|c|c|c|c|}
\hline \multirow{2}{*}{$\begin{array}{l}\text { Parental } \\
\text { protein }\end{array}$} & \multirow[b]{2}{*}{ Residue } & \multirow[b]{2}{*}{ Amino acid sequence ${ }^{a}$} & \multirow{2}{*}{$\frac{\mathrm{HM}}{\text { Undig }}$} & \multirow{2}{*}{$\begin{array}{l}\mathrm{HM} \\
\text { Dig }\end{array}$} & \multirow{2}{*}{$\begin{array}{c}\text { Past HM } \\
\text { Dig }\end{array}$} & \multirow[b]{2}{*}{ Function $^{b}$} & \multirow[b]{2}{*}{ Reference } \\
\hline & & & & & & & \\
\hline \multirow[t]{14}{*}{$\beta-\mathrm{CN}$} & $1-18$ & RETIESLSSSEEESITEYK & $\mathrm{Y}$ & Y & $\mathrm{Y}$ & CPP homologue (1-18) & 14 \\
\hline & $1-23$ & RETIESLSSSEESITEYKQKVEK & $\mathrm{Y}$ & Y & $\mathrm{Y}$ & CPP homologue (1-23) & 14 \\
\hline & $48-52$ & PLIYP & $\mathrm{N}$ & Y & $\mathrm{N}$ & ACEi (48-52) & 17 \\
\hline & $50-53$ & IYPF & $\mathrm{N}$ & Y & $\mathrm{Y}$ & $A O$ and PEPi (50-53) & 18,19 \\
\hline & $50-58$ & IYPFVEPIP & $\mathrm{N}$ & Y & $\mathrm{Y}$ & $\begin{array}{l}\text { PEPi }(50-58) \text { and } \\
\text { OP }(51-58, \text { etc.) }\end{array}$ & 19,20 \\
\hline & $52-59$ & PFVEPIPY & $\mathrm{N}$ & Y & $\mathrm{Y}$ & PEPi (52-59) & 19 \\
\hline & $53-59$ & FVEPIPY & $\mathrm{N}$ & $\mathrm{N}$ & $\mathrm{Y}$ & $\begin{array}{l}\text { PEPi (53-59) and } \\
\text { Immunomodulatory (54-59) }\end{array}$ & 19,21 \\
\hline & $54-59$ & VEPIPY & $\mathrm{N}$ & $\mathrm{N}$ & Y & Immunomodulatory (54-59) & 21 \\
\hline & $121-131$ & LENLHLPLPLL & $\mathrm{N}$ & Y & $\mathrm{Y}$ & $\begin{array}{l}\text { PEPi }(122-131) \text { and ACEi } \\
(125-129, \text { etc.) }\end{array}$ & $17,22,23$ \\
\hline & $122-129$ & ENLHLPLP & $\mathrm{N}$ & Y & $\mathrm{Y}$ & ACEi (122-129) & 17,22 \\
\hline & $122-131$ & ENLHLPLPLL & $\mathrm{N}$ & Y & Y & $\begin{array}{l}\text { PEPi (122-131) and ACEi } \\
(125-129, \text { etc.) }\end{array}$ & $17,22,23$ \\
\hline & $123-132$ & NLHLPLPLLQ & $\mathrm{N}$ & Y & Y & $\begin{array}{l}\text { PEPi }(122-131) \text { and ACEi } \\
(125-129, \text { etc.) }\end{array}$ & $17,22,23$ \\
\hline & $125-130$ & HLPLPL & $\mathrm{N}$ & $\mathrm{N}$ & $\mathrm{Y}$ & $\begin{array}{l}\text { ACEi (125-129) and PEPi } \\
(125-130)\end{array}$ & 19,22 \\
\hline & $154-160$ & WSVPQPK & $\mathrm{N}$ & Y & $\mathrm{Y}$ & $\mathrm{AO}(154-160)$ & 18 \\
\hline \multirow[t]{2}{*}{$\kappa-C N$} & $100-103$ & IPPK & $\mathrm{N}$ & Y & $\mathrm{Y}$ & Antithrombotic (101-103) & 27 \\
\hline & $101-104$ & PPKK & $\mathrm{N}$ & Y & $\mathrm{Y}$ & Antithrombotic (101-103) & 27 \\
\hline \multirow[t]{2}{*}{$\alpha-L A$} & $51-59$ & GLFQISNK & $\mathrm{N}$ & Y & $\mathrm{Y}$ & Immunomodulatory (51-53) & 21 \\
\hline & $104-108$ & WLAHK & $\mathrm{N}$ & $\mathrm{Y}$ & $\mathrm{Y}$ & ACEi (104-108) & 28 \\
\hline \multirow[t]{3}{*}{ LF } & $566-573$ & DLKLADFA & $\mathrm{N}$ & Y & Y & $\begin{array}{l}\text { ACEi (567-569) and AO } \\
(570-572)\end{array}$ & 29,30 \\
\hline & $566-574$ & DLKLADFAL & $\mathrm{N}$ & Y & $\mathrm{N}$ & $\begin{array}{l}\text { ACEi (567-569 and } \\
572-574) \text { and AO (570-572) }\end{array}$ & 29,30 \\
\hline & $567-572$ & $L K L A D F$ & $\mathrm{~N}$ & Y & Y & $\begin{array}{l}\text { ACEi (567-569) and AO } \\
(570-572)\end{array}$ & 29,30 \\
\hline
\end{tabular}

an the amino acid sequence column, peptides in italic indicate possible precursors for bioactive peptides, which include bioactive sequences. As for the amino acid sequences of caseinophosphopeptide (CPP) homologues, letters underscored indicate phosphorylated sites, and bold letters represent the "acid motif." bln the function column, the abbreviations ACEi, AO, PEPi, and OP denote angiotensin l-converting enzyme-inhibitory, antioxidative, prolyl endopeptidase-inhibitory, and opioidpeptide, respectively. Dig, digested; HM, human milk; Past, pasteurized; Undig, undigested.

circulation. It should be added that this peptide also inhibits prolyl endopeptidase (PEP) in vitro and is possibly involved in learning and memory processes (19), although its role in neonatal physiology has not been studied. While the peptide of residues 51-59 was still present after in vitro digestion of HM and pasteurized HM, shorter peptides such as an immunomodulatory peptide (residues 54-59) (21) and PEP-inhibitory
(PEPi) peptides (residues 52-59, 53-59, and 56-59) (19) were identified only after digestion. Thus, gastrointestinal digestion would be required for the formation of these shorter bioactive peptide and they would be released from intact $\beta-\mathrm{CN}$ as well as the precursor peptide (residues 51-59). The last bioactive peptide in undigested HM was a peptide of residues 185-211, known as an antibacterial peptide (24). This peptide was also 


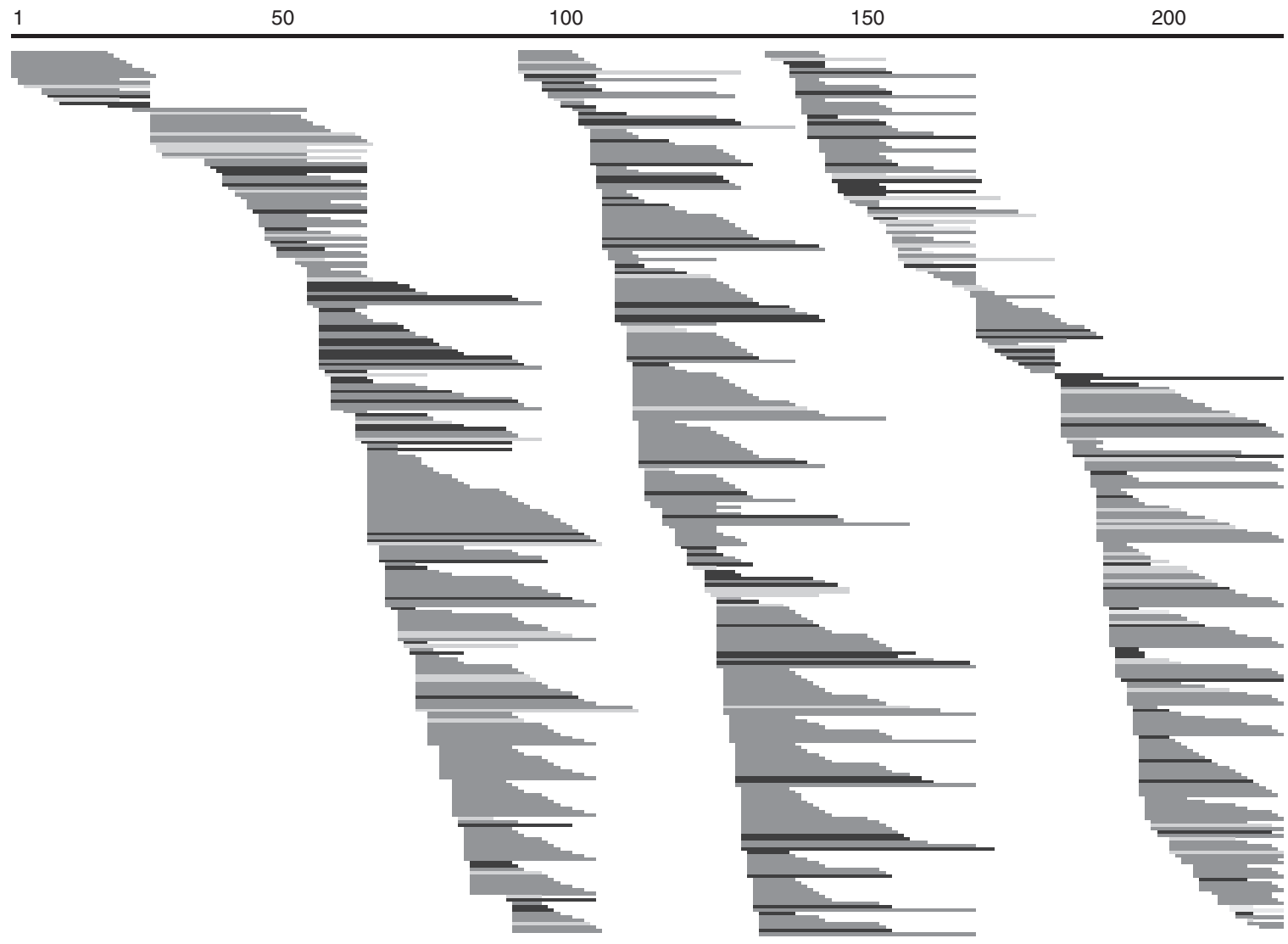

Figure 2. Digestive patterns for $\beta$-casein ( $\beta-C N)$ in human milk $(H M)$ and pasteurized $H M$. Sequences of $\beta$-CN-derived peptides released from HM and pasteurized HM were compared after in vitro digestion. The top line bar with numbers represents the whole $\beta$ - $\mathrm{CN}$ sequence with amino acid residue numbers. Bars in light gray, medium gray, and dark gray indicate peptides specific to HM, peptides in both HM and pasteurized HM, and peptides specific to pasteurized HM, respectively.

identified after digestion of pasteurized HM (though not observed in digested HM), suggesting that this peptide should be considerably resistant to gastrointestinal digestion, and possibly being involved in prevention of infection in the gastrointestinal tract.

In vitro digestion released a multitude of bioactive peptides from $\beta-\mathrm{CN}$, and one of the noteworthy regions may be residues 121-132. This region provides a PEPi peptide, previously investigated as an anticancer peptide (residues 122-131) (23), an ACEi peptide (residues 122-129) (17) and another PEPi peptide, studied in the context of learning and memory processes (residues 125-130) (19). While their roles in vivo have scarcely been investigated, all these peptides would also be precursors for a potent ACEi peptide of residues 125-129 (HLPLP) (22). A Caco-2 cell study has demonstrated that a longer peptide (residues 124-129) is hydrolyzed to residues $125-129$ in the course of transport across the intestinal epithelium, and the residues 125-129 exhibited high resistance to proteolysis in human plasma (34). Despite the limitation in our knowledge of their mechanism of action, milk protein-derived ACEi peptides as well as their precursors may be involved in the modulation of cardiovascular disease later in life (11). Other notable bioactive peptides are antioxidative, such as residues 50-53, 154-160, 167-173, and 206-209 (18,25). Although they have rarely been investigated in vivo, they may protect newborn infants from diseases mediated by oxidative stress.

\section{$\alpha_{\mathrm{s} 1}$-CN-Derived Bioactive Peptides}

While bovine $\alpha_{\mathrm{S} 1}$-CN constitutes a majority of bovine milk proteins, the amount of the human counterpart is very small (16), and bioactive peptides derived from human $\alpha_{S_{1}}$ CN have received limited attention. Formation of three ACEi peptides has been reported after in vitro tryptic digestion of recombinant $\alpha_{\mathrm{S} 1}-\mathrm{CN}$ (residues 8-11, 136-143, and 164-170) (26), and we identified two longer and one shorter sequences including/ overlapping the above-mentioned ACEi peptides in digested HM and pasteurized HM (residues 5-11, 136-142, and 160170). These peptides may thus serve as ACEi peptides and/or propeptides.

\section{א-CN-Derived Bioactive Peptides}

$\kappa-\mathrm{CN}$, a minor $\mathrm{CN}$ subunit, serves to stabilize casein micelles in milk because of its highly glycosylated C-terminus, and this glycosylated region also functions as a prebiotic and an inhibitor of infection (11). While we identified no notable fragment derived from $\kappa-\mathrm{CN}$ that completely matches known bioactive peptides, both HM and pasteurized HM released two peptides of residues 100-103 and 101-104, which are longer than an antithrombotic peptide (PPK) by one amino acid residue (27). 


\section{Articles | Wada and Lönnerdal}

Table 2. Peptide sequences derived from osteopontin

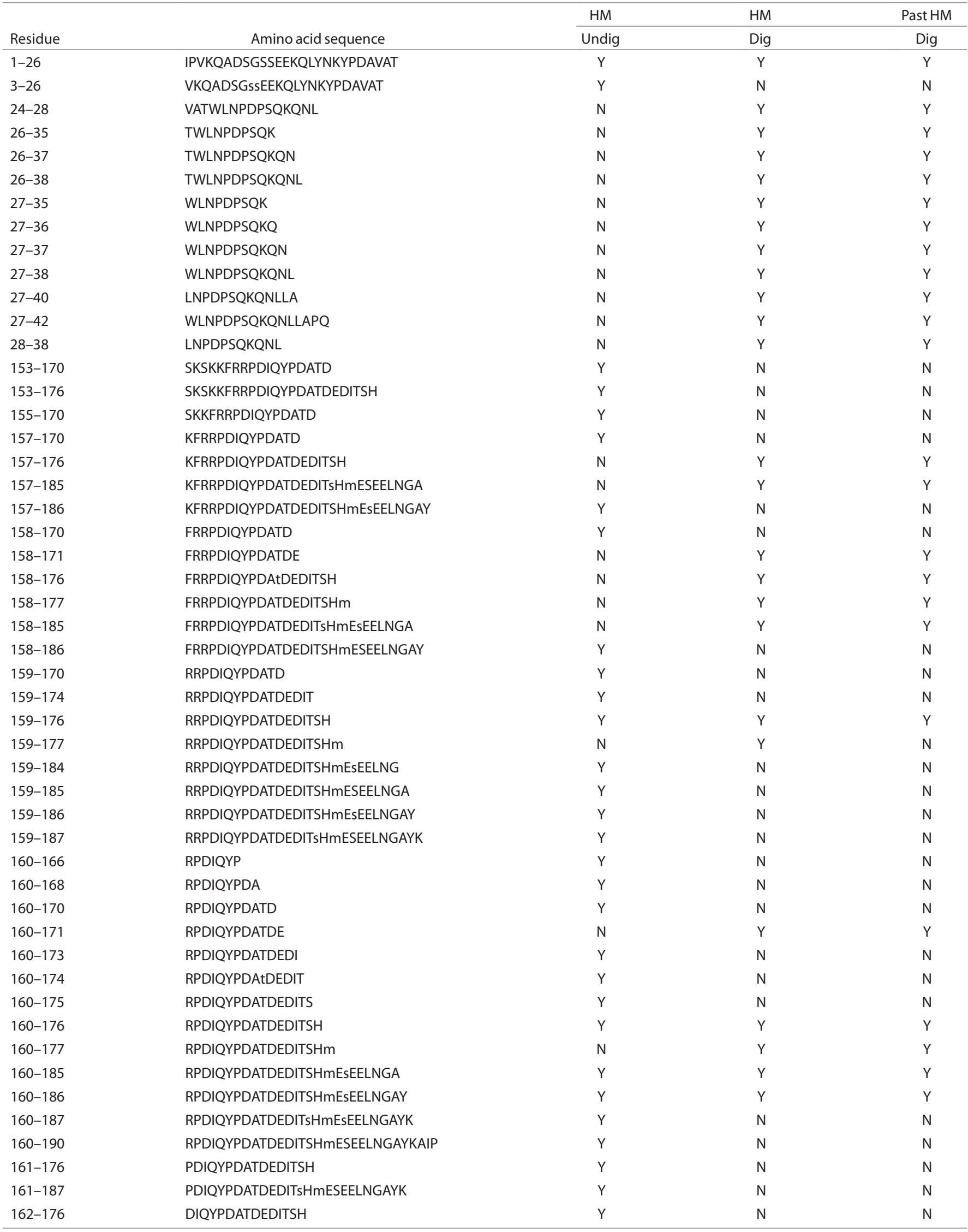

Table 2. Continued on next page 
Table 2. Continued

\begin{tabular}{|c|c|c|c|c|}
\hline & & $\mathrm{HM}$ & $\mathrm{HM}$ & Past HM \\
\hline Residue & Amino acid sequence & Undig & Dig & Dig \\
\hline $162-177$ & DIQYPDATDEDITSHm & Y & $\mathrm{N}$ & $\mathrm{N}$ \\
\hline $163-176$ & IQYPDATDEDITSH & $\mathrm{Y}$ & $\mathrm{N}$ & $\mathrm{N}$ \\
\hline $163-187$ & IQYPDATDEDITSHmESEELNGAYK & Y & $\mathrm{N}$ & $\mathrm{N}$ \\
\hline $164-176$ & QYPDATDEDITSH & Y & $\mathrm{N}$ & $\mathrm{N}$ \\
\hline $170-187$ & DEDITSHmEsEELNGAYK & $\mathrm{Y}$ & $\mathrm{N}$ & $\mathrm{N}$ \\
\hline $171-187$ & EDITsHmESEELNGAYK & Y & $\mathrm{N}$ & $\mathrm{N}$ \\
\hline $172-186$ & DITSHmESEELNGAY & Y & $\mathrm{N}$ & $\mathrm{N}$ \\
\hline $172-187$ & DITsHmESEELNGAYK & Y & $\mathrm{N}$ & $\mathrm{N}$ \\
\hline $183-200$ & NGAYKAIPVAQDLNAPSD & $\mathrm{Y}$ & $\mathrm{N}$ & $\mathrm{N}$ \\
\hline $186-204$ & YKAIPVAQDLNAPSDWDSR & $\mathrm{N}$ & $\mathrm{Y}$ & Y \\
\hline $186-214$ & YKAIPVAQDLNAPSDWDSRGKDSYETSQ & $\mathrm{N}$ & Y & $\mathrm{Y}$ \\
\hline $187-204$ & KAIPVAQDLNAPSDWDSR & $\mathrm{N}$ & Y & $\mathrm{Y}$ \\
\hline $187-214$ & KAIPVAQDLNAPSDWDsRGKDsYETSQL & $\mathrm{N}$ & Y & $\mathrm{Y}$ \\
\hline $188-204$ & AIPVAQDLNAPSDWDSR & $\mathrm{N}$ & Y & $\mathrm{Y}$ \\
\hline $188-213$ & AIPVAQDLNAPSDWDSRGKDSYETSQ & $\mathrm{N}$ & Y & $\mathrm{Y}$ \\
\hline 189-199 & IPVAQDLNAPS & Y & $\mathrm{N}$ & $\mathrm{N}$ \\
\hline $189-200$ & IPVAQDLNAPSD & Y & $\mathrm{N}$ & $\mathrm{N}$ \\
\hline $190-200$ & PVAQDLNAPSD & Y & $\mathrm{N}$ & $\mathrm{N}$ \\
\hline $213-230$ & QLDDQSAETHSHKQSRLY & $\mathrm{Y}$ & $\mathrm{N}$ & $\mathrm{N}$ \\
\hline $215-230$ & DDQSAETHSHKQSRLY & $\mathrm{Y}$ & $\mathrm{N}$ & $\mathrm{N}$ \\
\hline $216-230$ & DQSAEtHSHKQSRLY & Y & $\mathrm{N}$ & $\mathrm{N}$ \\
\hline $232-254$ & RKANDEsNEHSDVIDsQELSKVS & $\mathrm{Y}$ & $\mathrm{N}$ & $\mathrm{N}$ \\
\hline $233-254$ & KANDEsNEHSDVIDsQELSKVS & Y & $\mathrm{N}$ & $\mathrm{N}$ \\
\hline $235-254$ & NDESNEHSDVIDSQELSKVS & Y & $\mathrm{N}$ & $\mathrm{N}$ \\
\hline $236-251$ & DESNEHSDVIDSQELS & Y & $\mathrm{N}$ & $\mathrm{N}$ \\
\hline $358-274$ & HsHEFHsHEDmLVVDPK & $\mathrm{Y}$ & $\mathrm{N}$ & $\mathrm{N}$ \\
\hline $268-279$ & mLVVDPKSKEED & Y & $\mathrm{N}$ & $\mathrm{N}$ \\
\hline $269-282$ & LVVDPKSKEEDKHL & $\mathrm{N}$ & $\mathrm{N}$ & $\mathrm{Y}$ \\
\hline $269-283$ & LVVDPKsKEEDKHLK & $\mathrm{N}$ & $\mathrm{Y}$ & $\mathrm{Y}$ \\
\hline $275-287$ & SKEEDKHLKFRIS & $\mathrm{Y}$ & $\mathrm{N}$ & $\mathrm{N}$ \\
\hline $275-298$ & SKEEDKHLKFRISHELDSASsEVN & $\mathrm{Y}$ & $\mathrm{N}$ & $\mathrm{N}$ \\
\hline $277-287$ & EEDKHLKFRIS & $\mathrm{Y}$ & $\mathrm{N}$ & $\mathrm{N}$ \\
\hline $284-298$ & FRISHELDSASSEVN & $\mathrm{Y}$ & Y & Y \\
\hline $285-298$ & RISHELDSASSEVN & $\mathrm{Y}$ & Y & Y \\
\hline $286-298$ & ISHELDSASSEVN & $\mathrm{Y}$ & $\mathrm{Y}$ & $\mathrm{N}$ \\
\hline $286-298$ & ISHELDSASsEVN & $Y$ & $\mathrm{~N}$ & $\mathrm{~N}$ \\
\hline $287-298$ & SHELDSASSEVN & Y & $\mathrm{N}$ & $\mathrm{N}$ \\
\hline
\end{tabular}


The peptide MAIPPK derived from bovine $\mathrm{\kappa}$ - $\mathrm{CN}$ also contains PPK and exerts antithrombotic activity (27), and it is therefore plausible that the above two peptides would also be antithrombotic, possibly involved in modulating risk of cardiovascular disease later in life.

\section{$\alpha$-LA-Derived Bioactive Peptides}

Whey protein comprises $\sim 60 \%$ of human milk protein, and the major component is $\alpha$-lactalbumin (16). $\alpha$-Lactalbumin is a rich source of essential amino acids and of central importance to the rapidly growing neonate (35), and it has also been reported to provide various bioactive peptides (11). In vitro digestion of HM and pasteurized HM released an ACEi peptide (residues 104-108) (28). The formation of this fragment has also been confirmed by in vitro digestion of a standard infant formula and of a protein hydrolysate formula (Y. Wada and B. Lönnerdal, unpublished data), suggesting that considerable resistance to proteolysis may guarantee its functionality in vivo.

\section{LF-Derived Bioactive Peptides}

LF is another abundant whey protein in HM (16). This protein possesses several health promoting functions, and it also encrypts unique bioactive peptides, such as lactoferricin and prebiotic peptides (11). However, these peptides were not detected in this study, presumably due to presence of disulfide bonds within these peptides, making it difficult to identify them with this analytic method. Although the three peptides of residues 566-573, 566-574, and 567-572 contain ACEi peptides (residues 567-569 and 572-574) and an antioxidative peptide (residues 570-572), which was originally identified from sardine and soybean protein $(29,30)$, information about these peptides is scarce and it is therefore uncertain whether they may be active in vivo.

\section{OPN-Derived Peptides}

OPN is a heavily glycosylated and phosphorylated protein and is also present in a relatively high concentration in human milk $(16,36)$. It is a multifunctional protein involved in many physiologic processes such as regulation of immune function (31). However, bioactive peptides derived from it have not been investigated to date, and no peptide was found that corresponds to any known bioactive peptides.

Peptides were present in undigested HM, and most of them are vulnerable to proteolysis as they disappeared after in vitro digestion. Other peptides were released after in vitro digestion and showed quite similar profiles in HM and pasteurized HM. Interestingly, there was no peptide identified which was released from residues 29-153, and Dallas et al. also reported a similar observation (15). One possible explanation can be attributed to five glycosylation sites of OPN in human milk, all of which are located in residues 29-153 (36); glycosylated peptides are possibly released but lack of information regarding exact oligosaccharide structures makes them impossible to be identified by this peptidomic method. As OPN isoforms seem to exert different bioactivities depending on their glycosylation moieties (R. Jiang and B. Lönnerdal, unpublished data), structural elucidation would be warranted for identifying and characterizing novel glycopeptides from OPN. It is also probable that glycosylation moieties may block the access of digestive enzymes, thereby hindering the release of peptides.

In conclusion, pasteurized HM may be as beneficial as breastfeeding in terms of providing bioactive peptides, such as ACEi, antibacterial, caseinophosphopeptides, and immunomodulatory peptides as discussed above. These peptides may contribute to the growth, development and health of neonates. However, in vivo investigations will be required to substantiate the above conclusions, as well as to verify which of the observed bioactive peptides are of biological significance for infants.

\section{METHODS}

\section{Samples}

This study procedure was approved by the Institutional Review Board at the University of California, Davis. HM samples were obtained from a volunteer mother, from whom informed consent was obtained, at different lactation days and were pooled. Part of the sample was pasteurized at $62.5^{\circ} \mathrm{C}$ for $30 \mathrm{~min}$ in a water bath. Both $\mathrm{HM}$ and pasteurized $\mathrm{HM}$ were stored at $-20^{\circ} \mathrm{C}$ until further analysis.

\section{In Vitro Digestion of Milk Samples}

Milk samples were skimmed twice by centrifugation at $8,500 \mathrm{~g}$ for $30 \mathrm{~min}$ and then subjected to in vitro digestion (13). After protein concentration was determined by the Bradford method (37), simulated gastric digestion was started with adjusting the $\mathrm{pH}$ to 4.0 (mimicking the stomach $\mathrm{pH}$ in infants) with $1 \mathrm{~mol} / \mathrm{l} \mathrm{HCl}$. Porcine pepsin (Sigma-Aldrich, St Louis, $\mathrm{MO} ; 2 \%$ in $1 \mathrm{mmol} / \mathrm{l} \mathrm{HCl}$ ) was added to the sample in a 1:12.5 ratio (pepsin:protein). Samples were placed in an incubating shaker (New Brunswick Scientific, Edison, NJ) at $140 \mathrm{rpm}$ at $37^{\circ} \mathrm{C}$ for $15 \mathrm{~min}$. Then, after the $\mathrm{pH}$ of the samples was adjusted to 7.0 with $0.1 \mathrm{~mol} / \mathrm{l}$ $\mathrm{NaHCO}_{3}$, simulated intestinal digestion was performed. Pancreatin (Sigma-Aldrich; $0.4 \%$ in $0.1 \mathrm{~mol} / 1 \mathrm{NaHCO}_{3}$ ) was added to the samples in a 1:62.5 ratio (pancreatin:protein), and the samples were placed in the incubator shaker at $140 \mathrm{rpm}$ at $37^{\circ} \mathrm{C}$ for $5 \mathrm{~min}$. After the incubation, the enzymes were inactivated in a water bath at $85^{\circ} \mathrm{C}$ for $3 \mathrm{~min}$.

\section{Peptidomic Analysis}

Peptidomic analysis was conducted at the Proteomic Core Facility at the University of California, Davis, using a similar method as described previously (13). Undigested HM, digested HM, and digested pasteurized HM samples were spun with a $10 \mathrm{kDa}$ filter (Millipore, Bedford, MA). The collected filtrate was subject to solid phase extraction using Aspire Chromatography Tips (Thermo Scientific, San Jose, CA). The desalted peptides were reconstituted in $2 \%$ acetonitrile $/ 0.1 \%$ trifluoroacetic acid and $10 \mu \mathrm{l}$ of each sample was loaded onto a $100 \mu \mathrm{m} \times 25 \mathrm{~mm}$ Magic C18 $100 \AA 5 \mathrm{U}$ reverse phase trap before being separated on a $75 \mu \mathrm{m} \times 150 \mathrm{~mm}$ Magic C18 $200 \AA 3 U$ reverse phase column. Peptides were eluted using a gradient of buffer A ( $0.1 \%$ formic acid) and buffer B ( $100 \%$ acetonitrile) with a flow rate of $300 \mathrm{nl} / \mathrm{min}$. A $60 \mathrm{~min}$ gradient was run with $5-35 \%$ B over $45 \mathrm{~min}, 35-80 \%$ B over $5 \mathrm{~min}, 80 \%$ B for $1 \mathrm{~min}, 80-$ $5 \% \mathrm{~B}$ over $1 \mathrm{~min}$, and held at $5 \% \mathrm{~B}$ for $8 \mathrm{~min}$. Tandem mass spectra were extracted and charge states were deconvoluted and deisotoped. All MS/MS samples were analyzed using X! Tandem (The GPM, thegpm.org; version CYCLONE (2013.02.01.2). X! Tandem was set up to search the Human reference database (May 2013; 20,252 entries) plus an equal number of reverse sequences and 60 common laboratory contaminant proteins, assuming a non-specific digestion enzyme. X! Tandem was searched with a fragment ion mass tolerance of $20 \mathrm{ppm}$ and a parent ion tolerance of $20 \mathrm{ppm}$. Glu->pyro-Glu of the N-terminus, ammonia-loss of the N-terminus, gln->pyro-Glu of the N-terminus, deamidation of asparagine and glutamine, oxidation of methionine and tryptophan, and dioxidation of methionine and tryptophan were specified in X! Tandem as variable modifications. Scaffold (version Scaffold_4.2.1, Proteome Software, Portland, 
OR) and SEQUEST (Proteome Discoverer 1.1; Thermo Scientific) were used to validate MS/MS based peptide and protein identifications with the criteria as described previously (38-41) Peptides derived from major HM proteins were compared with the database of BIOPEP (42), and the search results were further corroborated by browsing reference articles.

\section{ACKNOWLEDGMENTS}

We are grateful to Brett Phinney and Darren Weber, University of California, Davis, for performing the proteomic analysis.

Disclosure: The authors declare no conflict of interest.

\section{REFERENCES}

1. Owen CG, Whincup PH, Gilg JA, Cook DG. Effect of breast feeding in infancy on blood pressure in later life: systematic review and meta-analysis. BMJ 2003;327:1189-95.

2. Owen CG, Martin RM, Whincup PH, Smith GD, Cook DG. Effect of infant feeding on the risk of obesity across the life course: a quantitative review of published evidence. Pediatrics 2005;115:1367-77.

3. Owen CG, Martin RM, Whincup PH, Smith GD, Cook DG. Does breastfeeding influence risk of type 2 diabetes in later life? A quantitative analysis of published evidence. Am J Clin Nutr 2006;84:1043-54.

4. Tully DB, Jones F, Tully MR. Donor milk: what's in it and what's not. J Hum Lact 2001;17:152-5.

5. Hamprecht K, Maschmann J, Müller D, et al. Cytomegalovirus (CMV) inactivation in breast milk: reassessment of pasteurization and freezethawing. Pediatr Res 2004;56:529-35.

6. Andersson Y, Sävman K, Bläckberg L, Hernell O. Pasteurization of mother's own milk reduces fat absorption and growth in preterm infants. Acta Paediatr 2007;96:1445-9.

7. Moltó-Puigmartí C, Permanyer M, Castellotea AI, López-Sabater MC. Effects of pasteurisation and high-pressure processing on vitamin $\mathrm{C}$, tocopherols and fatty acids in mature human milk. Food Chem 2011;124:697-702.

8. Akinbi H, Meinzen-Derr J, Auer C, et al. Alterations in the host defense properties of human milk following prolonged storage or pasteurization. J Pediatr Gastroenterol Nutr 2010;51:347-52.

9. Ley SH, Hanley AJ, Stone D, O'Connor DL. Effects of pasteurization on adiponectin and insulin concentrations in donor human milk. Pediatr Res 2011;70:278-81.

10. Lönnerdal B. Nutritional and physiologic significance of human milk proteins. Am J Clin Nutr 2003;77:1537S-43S.

11. Wada Y, Lönnerdal B. Bioactive peptides derived from human milk proteins-mechanisms of action. J Nutr Biochem 2014;25:503-14.

12. Mauron J. Influence of processing on protein quality. J Nutr Sci Vitaminol 1990;36:Suppl 1:S57-69.

13. Wada Y, Lönnerdal B. Effects of different industrial heating processes of milk on site-specific protein modifications and their relationship to in vitro and in vivo digestibility. J Agric Food Chem 2014;62:4175-85.

14. Ferranti P, Traisci MV, Picariello G, et al. Casein proteolysis in human milk: tracing the pattern of casein breakdown and the formation of potential bioactive peptides. J Dairy Res 2004;71:74-87.

15. Dallas DC, Guerrero A, Khaldi N, et al. Extensive in vivo human milk peptidomics reveals specific proteolysis yielding protective antimicrobial peptides. J Proteome Res 2013;12:2295-304.

16. Chatterton DE, Nguyen DN, Bering SB, Sangild PT. Anti-inflammatory mechanisms of bioactive milk proteins in the intestine of newborns. Int $\mathrm{J}$ Biochem Cell Biol 2013;45:1730-47.

17. Kohmura M, Nio N, Kubo K, Minoshima Y, Munekata E, Ariyoshi Y. Inhibition of angiotensin-converting enzyme by synthetic peptides of human $\beta$-casein. Agric Biol Chem 1989;53:2107-14.

18. Hernández-Ledesma B, Quirós A, Amigo L, Recio I. Identification of bioactive peptides after digestion of human milk and infant formula with pepsin and pancreatin. Int Dairy J 2007;17:42-9.

19. Asano M, Nio N, Ariyoshi Y. Inhibition of prolyl endopeptidase by synthetic peptide fragments of human beta-casein. Agric Biol Chem 1991;55:825-8.
20. Koch G, Wiedemann K, Teschemacher H. Opioid activities of human betacasomorphins. Naunyn Schmiedebergs Arch Pharmacol 1985;331:351-4.

21. Migliore-Samour D, Jollès P. Casein, a prohormone with an immunomodulating role for the newborn? Experientia 1988;44:188-93.

22. Miguel M, Recio I, Ramos M, Delgado MA, Aleixandre MA. Antihypertensive effect of peptides obtained from Enterococcus faecalis-fermented milk in rats. J Dairy Sci 2006;89:3352-9.

23. Juillerat-Jeanneret L, Robert MC, Juillerat MA. Peptides from Lactobacillus hydrolysates of bovine milk caseins inhibit prolyl-peptidases of human colon cells. J Agric Food Chem 2011;59:370-7.

24. Minervini F, Algaron F, Rizzello CG, Fox PF, Monnet V, Gobbetti M. Angiotensin I-converting-enzyme-inhibitory and antibacterial peptides from Lactobacillus helveticus PR4 proteinase-hydrolyzed caseins of milk from six species. Appl Environ Microbiol 2003;69:5297-305.

25. Tsopmo A, Romanowskia A, Bandab L, Lavoiec JC, Jenssend H, Friele JK. Novel anti-oxidative peptides from enzymatic digestion of human milk. Food Chem 2011;126:1138-43.

26. Kim YK, Yoon S, Yu DY, Lönnerdal B, Chung BH. Novel angiotensin-Iconverting enzyme inhibitory peptides derived from recombinant human alpha s1-casein expressed in Escherichia coli. J Dairy Res 1999;66:431-9.

27. Hayes M, Stanton C, Fitzgerald GF, Ross RP. Putting microbes to work: dairy fermentation, cell factories and bioactive peptides. Part II: bioactive peptide functions. Biotechnol J 2007;2:435-49.

28. Pihlanto-Leppälä A, Koskinen P, Piilola $K$, Tupasela $T$, Korhonen $H$. Angiotensin I-converting enzyme inhibitory properties of whey protein digests: concentration and characterization of active peptides. J Dairy Res 2000;67:53-64.

29. Ukeda H, Matsuda H, Osajima K, Matsufuji H, Matsui T, Osajima Y. Peptides from peptic hydrolysate of heated sardine meat that inhibit angiotensin I converting enzyme. Nippon Nogeikagaku Kaishi 1992;66:25-9.

30. Yokomizo A, Takenaka Y, Takenaka T. Antioxidative activity of peptides prepared from okara protein. Food Sci Technol Res 2002;8:357-9.

31. Lönnerdal B. Infant formula and infant nutrition: bioactive proteins of human milk and implications for composition of infant formulas. Am J Clin Nutr 2014;99:712S-7S.

32. Cossey V, Vanhole C, Eerdekens A, Rayyan M, Fieuws S, Schuermans A. Pasteurization of mother's own milk for preterm infants does not reduce the incidence of late-onset sepsis. Neonatology 2013;103:170-6.

33. Panchaud A, Affolter M, Kussmann M. Mass spectrometry for nutritional peptidomics: How to analyze food bioactives and their health effects. J Proteomics 2012;75:3546-59.

34. Quirós A, Dávalos A, Lasunción MA, Ramos M, Recio I. Bioavailability of the antihypertensive peptide LHLPLP: Transepithelial flux of HLPLP. Int Dairy J 2008;18:279-86.

35. Lönnerdal B, Lien EL. Nutritional and physiologic significance of alphalactalbumin in infants. Nutr Rev 2003;61:295-305.

36. Christensen B, Nielsen MS, Haselmann KF, Petersen TE, Sørensen ES, Post-translationally modified residues of native human osteopontin are located in clusters: identification of 36 phosphorylation and five O-glycosylation sites and their biological implications. Biochem J 2005;390(Pt 1):285-92.

37. Bradford MM. A rapid and sensitive method for the quantitation of microgram quantities of protein utilizing the principle of protein-dye binding. Anal Biochem 1976;72:248-54.

38. Keller A, Nesvizhskii AI, Kolker E, Aebersold R. Empirical statistical model to estimate the accuracy of peptide identifications made by MS/MS and database search. Anal Chem 2002;74:5383-92.

39. Nesvizhskii AI, Keller A, Kolker E, Aebersold R. A statistical model for identifying proteins by tandem mass spectrometry. Anal Chem 2003; 75:4646-58.

40. Elias JE, Gygi SP. Target-decoy search strategy for mass spectrometrybased proteomics. Methods Mol Biol 2010;604:55-71.

41. Katz E, Fon M, Eigenheer RA, et al. A label-free differential quantitative mass spectrometry method for the characterization and identification of protein changes during citrus fruit development. Proteome Sci 2010;8:68.

42. Dziuba J, Minkiewicz P, Nalecz D, Iwaniak A. Database of biologically active peptide sequences. Nahrung 1999;43:190-5. 